\title{
EFEKTIFITAS MEDIA PERTUMBUHAN MAGGOTS Hermetia illucens (Lalat Tentara Hitam) SEBAGAI SOLUSI PEMANFAATAN SAMPAH ORGANIK
}

\author{
Rizkia Suciati ${ }^{1}$, Hilman Faruq ${ }^{2}$ \\ ${ }^{1,2)}$ Jurusan Pendidikan Biologi, Universitas Muhammadiyah Prof. DR. HAMKA \\ Jl. Tanah Merdeka Pasar Rebo Kp. Rambutan 13830, Jakarta Timur \\ e-mail: rizkia_suciati@uhamka.ac.id
}

\begin{abstract}
Abstrak
Sampah organik seringkali menimbulkan bau dan penyakit. Belakangan ini, ditemukan kegiatan untuk mendaur ulang sampah organik dengan metode biokonversi. Umumnya, organisme yang berperan dalam proses biokonversi ini adalah bakteri, jamur, dan larva serangga. Larva serangga Hermetia illucens / Black Soldier Fly (BSF) ini sering digunakan sebagai agen biokonversi, dan lebih dikenal dengan istilah "maggot". Penelitian ini bertujuan untuk mengetahui pengaruh berbagai jenis media pertumbuhan maggot, dengan parameter biomassa maggot, wadah, dan kondisi media tumbuh maggot. Media yang dipakai adalah campuran dedak dengan ampas tahu, ampas kelapa, dan tulang ayam. Wadah yang digunakan yaitu ember dan keranjang. Berdasarkan hasil analisis, setiap dosis perlakuan (media) memiliki pengaruh terhadap biomassa maggot. Media campuran dedak dengan tulang ayam berpengaruh signifikan terhadap biomassa maggot, dibandingkan dengan media campuran dedak dengan ampas tahu dan campuran dedak dengan ampas kelapa. Besarnya nilai sig. berkisar $0.000-0.002$ (nilai sig. (tabel) < nilai sig. $\alpha$ (0.01)). Penggunaan wadah yang berbeda (ember dan keranjang) tidak berpengaruh terhadap biomassa maggot, dan kondisi media yang berminyak, serta terlalu basah (berair) tidak menghasilkan maggot.
\end{abstract}

Kata Kunci : maggot BSF, media, agen biokonversi, sampah organik

\begin{abstract}
Organic waste often causes odors and diseases. Recently, activities have been found to recycle organic waste by bioconversion methods. Generally, organisms that play a role in this bioconversion process are bacteria, fungi, and insect larvae. Insect larvae Hermetia illucens / Black Soldier Fly (BSF) is often used as a bioconversion agent, and more commonly known as "maggot". This study aims to determine the effect of various types of maggot growth media, with maggot biomass parameters, containers, and growing media conditions maggot. The medium used is a mixture of bran with tofu, coconut pulp, and chicken bone. The containers used are buckets and baskets. Based on the analysis, each treatment dose (medium) has an effect on maggot biomass. Bran-blended media with chicken bone had a significant effect on maggot biomass, compared to bran-mixed medium with tofu and bran-mixed mixture with coconut pulp. The value of sig. Ranges from $0.000-0.002$ ( sig. (Table) < sig. $\alpha(0.01)$ ). The use of different containers (buckets and baskets) has no effect on the maggot biomass, and the oily, too wet (watery) media conditions do not produce maggots.
\end{abstract}

Keyword : maggot BSF, media, biconversion agent, organic waste 


\section{PENDAHULUAN}

Sampah merupakan masalah lingkungan yang sangat serius yang dihadapi masyarakat Indonesia dan dunia. Bisa dikatakan sampah yang dihasilkan manusia setiap hari tidak terhitung jumlahnya, baik itu sampah organik maupun anorganik. Propinsi DKI Jakarta sebagai ibukota negara RI tercatat menghasilkan 6000 ton sampah setiap harinya, yang sekitar 65\%-nya adalah sampah organik. Dari jumlah sampah tersebut, 1400 ton dihasilkan oleh seluruh pasar yang ada di Jakarta, dan 95\%-nya adalah sampah organik. Melihat besarnya sampah organik yang dihasilkan oleh masyarakat, sudah terlihat umum jika sampah organik diolah menjadi pupuk organik, biogas, atau produk lainnya seperti daur ulang (kertas) demi kelestarian lingkungan dan kesejahteraan masyarakat.

Belakangan ini ditemukan kegiatan daur ulang sampah organik dengan metode biokonversi. Newton et al. (2005) mendefinisikan biokonversi sebagai perombakan sampah organik menjadi sumber energi metan melalui proses fermentasi yang melibatkan organisme hidup. Proses ini biasanya dikenal sebagai penguraian secara anaerob. Umumnya organisme yang berperan dalam proses biokonversi ini adalah bakteri, jamur dan larva serangga (family: Chaliforidae, Mucidae, Stratiomydae). Dalam kehidupan sehari-hari, proses ini sering ditemukan, seperti pada proses pembuatan tempe yang memanfaatkan jamur (ragi) sebagai organisme perombak, proses pembusukan sampah organik (pembuatan pupuk kompos) yang melibatkan bakteri sebagai organisme perombak. Sedangkan pada limbah hewani agen perombak yang sering ditemukan adalah larva serangga Diptera. Larva serangga dari famili: Stratiomydae, Genus: Hermetia, spesies: Hermetia illucens, banyak ditemukan pada limbah kelapa sawit. Larva Hermetia illucens atau Black Soldier Fly (BSF) ini, lebih dikenal dengan istilah "maggot".

Istilah "maggot" mulai dikenal pada pertengahan tahun 2005, yang diperkenalkan oleh tim Biokonversi IRD-Perancis dan Loka Riset Budidaya Ikan Hias Air Tawar (LRBIHAT), Depok. Maggot merupakan larva serangga (Diptera: Stratiomydae, Genus Hermetia) yang hidup di bungkil kelapa sawit (Fahmi, dkk., 2007).
Biokonversi yang dilakukan oleh agen biokonversi yaitu larva BSF (Black Soldier Fly) atau yang biasa disebut juga maggot, ternyata mampu mengurangi limbah organik hingga 56\% dan sebagai agen biokonversi, setidaknya ada tiga produk yang dapat diperoleh dengan memberdayakan larva BSF sebagai agen biokonversi. Produk pertama adalah larva atau pre-pupa BSF yang dapat dijadikan sebagai sumber protein alternatif untuk pakan ternak, produk kedua adalah cairan hasil aktivitas larva yang berfungsi sebagai pupuk cair dan yang ketiga adalah sisa limbah organik kering yang dapat dijadikan sebagai pupuk (BB Veteriner, 2016).

Budidaya maggot sebagai sumber pakan ternak kini sudah tidak asing lagi. Maggot atau larva dari lalat black soldier fly (Hermetia illicens) merupakan salah satu alternatif pakan yang memenuhi persyaratan sebagai sumber protein. Murtidjo (2001) menyebutkan bahwa bahan makanan yang mengandung protein kasar lebih dari $19 \%$, digolongkan sebagai bahan makanan sumber protein.

Lalat tentara hitam, Black Soldier fly (Hermetia illucens) ini tersebar hampir di seluruh dunia. Layaknya lalat lain, lalat tentara memakan apa saja yang telah dikonsumsi oleh manusia, seperti sisa makanan, sampah, makanan yang sudah terfermentasi, sayuran, buah buahan, daging bahkan tulang (lunak), bahkan makan bangkai hewan. Larva lalat (maggots) ini tergolong "kebal" dan dapat hidup di lingkungan yang cukup ekstrim, seperti di media/sampah yang banyak mengandung garam, alkohol, acids/asam dan amonia. Mereka hidup "di suasana yang hangat", dan jika udara lingkungan sekitar sangat dingin atau kekurangan makanan, maka maggots tidak mati tapi mereka menjadi fakum /idle/tidak aktif menunggu sampai cuaca menjadi hangat kembali atau makanan sudah kembali tersedia. Mereka juga dapat hidup di air atau dalam suasana alcohol. Serangga BSF memiliki beberapa karakter diantaranya: (1) dapat mereduksi sampah organik, (2) dapat hidup dalam toleransi $\mathrm{pH}$ yang cukup tinggi, (3) tidak membawa gen penyakit, (4) mempunyai kandungan protein yang cukup tinggi $(40-50 \%)$, (5) masa hidup sebagai larva cukup lama $( \pm 4$ minggu), dan (6) mudah dibudidayakan (Adrian, 2015). 
Dalam siklus hidupnya lalat Hermetia illucens memiliki lima stadia. Lima stadia tersebut yaitu fase dewasa, fase telur, fase prepupa, dan fase pupa. Dari ke-lima stadia tersebut stadia prepupa sering digunakan sebagai pakan ikan (Newton, 2005)

Lalat Hermetia illucens menyukai aroma media yang khas maka tidak semua media dapat dijadikan tempat bertelur bagi lalat Hermetia illucens (Katayane, dkk., 2014). Hartoyo dan Sukardi P. (2007) mengungkap bahwa walaupun kandungan nutrien media cukup bagus namun jika aroma media tidak dapat menarik lalat untuk bersarang maka tidak akan dihasilkan maggot.

Berdasarkan uraian di atas, keberhasilan produksi dan kualitas maggot yang dihasilkan melalui beberapa media pertumbuhan serta wadah perkembangbiakan maggot tersebut. Dengan demikian, efektivitas media pertumbuhan maggot dapat terlihat sehingga dapat menjadi solusi pemanfaatan sampah organik dan juga sebagai agen biokonversi yang nantinya dapat dijadikan sumber protein pakan bagi ternak.

\section{METODE PENELITIAN}

Penelitian ini merupakan jenis penelitian eksperimen, bertujuan untuk mengetahui pengaruh berbagai jenis media pertumbuhan maggot, dengan parameter yang diamati yaitu biomassa maggot, wadah, dan kondisi media tumbuh maggot. Data parameter yang diolah dianalisis statistik dengan Analisis One-way ANOVA (untuk wadah), dan General Linier Model (GLM) Multivariate, karena variabel bebasnya (media) lebih dari satu. Pengolahan data-data tersebut dilakukan dengan metode komputerisasi dengan bantuan Microsoft Office Excell dan IBM SPSS Statistic 21.

\section{A. Waktu dan Tempat Penelitian}

Penelitian ini dilakukan di 2 lokasi di daerah desa Jatiwaringin Mauk, Kabupaten Tanggerang, yaitu di Kebun Pohon Pisang dan Melinjo (milik peneliti) dan di pinggir kali (areal semak bunga Widelia). Penelitian dilakukan dari bulan September s.d. Desember 2016.
B. Alat dan Bahan Penelitian

Alat yang digunakan antara lain, wadah (ember plastik dengan tutup ukuran 5L dan keranjang ukuran 5L), gunting, pisau cutter, solder (pelubang ember), ayakan/saringan tampah, timbangan digital, timbangan manual, gayung, ember kecil, alat tulis, dan penggaris. Adapun bahan penelitian antara lain ampas tahu, ampas kelapa, tulang ayam, dedak, daun pisang, kardus karton, plastik fiber, dan air.

\section{Desain Penelitian}

Penelitian ini dibagi dalam 2 percobaan. Percobaan seri I dilakukan di kebun milik peneliti, dan Percobaan seri II dilakukan di pinggir kali. Desain penelitian yang digunakan ialah Rancangan Acak Kelompok Faktorial 4x3, dengan masing-masing 4 kali ulangan.

\section{Prosedur Penelitian}

Kegiatan penelitian ini dibagi dalam beberapa tahapan. Tahap pertama adalah tahap persiapan media dan wadah. Tahap kedua, menentukan lokasi penelitian. Tahap selanjutnya adalah tahapan budidaya, dan terakhir adalah kegiatan memanen larva BSF atau magggot yang sudah dikembangbiakan tersebut.

\section{E. Pembuatan Wadah}

Untuk wadah ember plastik, terlebih dahulu ember dilubangi kecil-kecil berdiameter $2 \mathrm{~cm}$, jarak antar lubang $6 \mathrm{~cm}$, ketinggian lubang $+10-$ $12 \mathrm{~cm}$ dari bawah ember. Untuk wadah keranjang, buat tutup sederhana dari plastik fiber. Di kedua wadah tersebut, taruh daun pisang yang kering di atas media (sebagai media lalat tentara hitam meletakkan telurnya). Dan letakkan wadah tersebut di lokasi yang telah ditentukan.

\section{F. Pembuatan Media Kultur Maggot}

Tiap wadah berisi dosis perlakuan yang berbeda, yaitu $500 \mathrm{~g}, 750 \mathrm{~g}$, dan $1 \mathrm{~kg}$. Media yang dipergunakan diperoleh dari pasar dan pabrik tahu. Untuk media tulang ayam, terlebih dahulu tulang-tulang ayam dicacah secara kasar. Setelah ditimbang sesuai dosis, baru dicampurkan dengan dedak sebagai kontrol sebanyak 50 g. Setiap dosis dicampur air sebanyak $500 \mathrm{ml}$, 
khusus untuk dedak cukup 50-100 ml. Air berfungsi sebagai pelarut agar media tidak terlalu kering, dan penambahan air dilakukan perlahan agar media tidak terlalu basah. Media diaduk secara merata dan digemburkan, lalu media yang telah siap dituang ke dalam wadah (Silmina, dkk., 2012). Wadah yang telah berisi media ditempatkan di lokasi yang sudah ditentukan, yaitu ditempat yang teduh dan terhindar dari air hujan.

\section{G. Panen Maggot}

Larva BSF (maggot) yang ada dalam media kultur dipanen setelah 2-3 minggu, cara pemanenan dengan menggunakan saringan/ tampah ayakan, maggot dipisahkan dari media kultur dan dari berbagai media kotoran lainnya, lalu ditimbang.

\section{HASIL DAN PEMBAHASAN}

\section{A. Biomassa Maggot BSF}

Berdasarkan hasil pengukuran biomassa maggot yang ditemukan di setiap media pertumbuhan (ampas tahu, ampas kelapa, tulang ayam yang dicampur dedak), terdapat jumlah biomassa yang berbeda di setiap wadah dan dosis media perlakuan, serta di kedua lokasi tersebut. Berikut hasil rata-rata biomassa maggot pada beberapa media dan wadah di Lokasi I (Tabel 1) dan Lokasi II (Tabel 2).

Tabel 1.

Hasil rata-rata biomassa maggot di Lokasi I

\begin{tabular}{|c|c|c|c|c|}
\hline \multirow[t]{2}{*}{ No } & \multirow[t]{2}{*}{ Media } & \multirow{2}{*}{$\begin{array}{c}\text { Dosis } \\
\text { (g) }\end{array}$} & \multicolumn{2}{|c|}{ Rata-rata Biomassa (g) } \\
\hline & & & Ember & Keranjang \\
\hline \multirow[t]{3}{*}{1} & ATD & 500 & 21.47 & 18.55 \\
\hline & & 750 & 57.65 & 55.90 \\
\hline & & $1 \mathrm{~kg}$ & 69.23 & 55.72 \\
\hline \multirow[t]{3}{*}{2} & AKD & 500 & 0 & 0 \\
\hline & & 750 & 0 & 0 \\
\hline & & $1 \mathrm{~kg}$ & 0 & 0 \\
\hline \multirow[t]{3}{*}{3} & TAD & 500 & 29.79 & 58.87 \\
\hline & & 750 & 58.87 & 71.15 \\
\hline & & $1 \mathrm{~kg}$ & 72.93 & 109.65 \\
\hline
\end{tabular}

Tabel 2.

Hasil rata-rata biomassa maggot di Lokasi II

\begin{tabular}{|c|c|c|c|c|}
\hline \multirow[t]{2}{*}{ No } & \multirow[t]{2}{*}{ Media } & \multirow{2}{*}{$\begin{array}{c}\text { Dosis } \\
\text { (g) }\end{array}$} & \multicolumn{2}{|c|}{ Rata-rata Biomassa (g) } \\
\hline & & & Ember & Keranjang \\
\hline \multirow[t]{3}{*}{1} & ATD & 500 & 0 & 0 \\
\hline & & 750 & 0 & 0 \\
\hline & & $1 \mathrm{~kg}$ & 0 & 0 \\
\hline \multirow[t]{3}{*}{2} & AKD & 500 & 0 & 0 \\
\hline & & 750 & 0 & 0 \\
\hline & & $1 \mathrm{~kg}$ & 0 & 0 \\
\hline \multirow[t]{3}{*}{3} & TAD & 500 & 10.67 & 15.49 \\
\hline & & 750 & 26.75 & 29.78 \\
\hline & & $1 \mathrm{~kg}$ & 45.00 & 31.75 \\
\hline
\end{tabular}

\section{B. Kondisi Media}

Hasil pengamatan terhadap kondisi media juga beragam di setiap wadah, dan lokasi. Berikut hasil pengamatan kondisi media yang tersaji dalam Tabel 3.

Tabel 3.

Hasil pengamatan kondisi media kultur maggot

\begin{tabular}{|c|c|c|c|c|}
\hline \multirow[t]{2}{*}{ No } & \multirow[t]{2}{*}{ Media } & \multirow{2}{*}{$\begin{array}{c}\text { Dosis } \\
\text { (g) }\end{array}$} & \multicolumn{2}{|c|}{ Rata-rata Biomassa (g) } \\
\hline & & & Ember & Keranjang \\
\hline \multirow[t]{3}{*}{1} & ATD & 500 & Berlendir & \\
\hline & & 750 & (jamur), bau & Basah, bau \\
\hline & & $1 \mathrm{~kg}$ & ammonia & pekat \\
\hline \multirow[t]{3}{*}{2} & AKD & 500 & & \\
\hline & & 750 & Berminyak & Basah, \\
\hline & & $1 \mathrm{~kg}$ & & \\
\hline \multirow[t]{3}{*}{3} & TAD & 500 & Kering & \\
\hline & & 750 & padatan & padatan \\
\hline & & $1 \mathrm{~kg}$ & & \\
\hline
\end{tabular}

Keterangan: ATD (Ampas Tahu Dedak), AKD (Ampas Kelapa Dedak), TAD (Tulang Ayam Dedak)

Secara umum hasil analisa penelitian menunjukkan bahwa campuran dedak pada media ampas tahu, ampas kelapa, dan tulang ayam mempengaruhi biomassa maggot yang dihasilkan (Tabel 4 dan 5). Hal ini terlihat dari jumlah maggot pada setiap media yang dihinggapi lalat BSF untuk meletakkan telurtelurnya. Sementara itu, pada media dedak (sebagai kontrol) tidak ditemukan maggot BSF. Itu berarti bahwa dedak tidak mampu mengundang lalat BSF di sekitar dua lokasi tersebut untuk bertelur. 


\begin{tabular}{|c|c|c|c|c|}
\hline \multicolumn{5}{|c|}{$\begin{array}{c}\text { Tabel } 4 . \\
\text { Hasil analisis perbandingan tiap dosis dengan biomassa maggot } \\
\text { Lokasi I dan II }\end{array}$} \\
\hline \multirow[t]{2}{*}{ No } & \multirow[t]{2}{*}{ Media } & \multirow{2}{*}{$\begin{array}{c}\text { Dosis } \\
\text { (g) }\end{array}$} & \multicolumn{2}{|c|}{ Nilai Signifikansi } \\
\hline & & & Lokasi I & Lokasi II \\
\hline \multirow[t]{3}{*}{1} & ATD -AKD & 500 & .002 & 1.000 \\
\hline & & 750 & .000 & 1.000 \\
\hline & & $1 \mathrm{~kg}$ & .000 & 1.000 \\
\hline \multirow[t]{3}{*}{2} & AKD - TAD & 500 & .000 & .000 \\
\hline & & 750 & .000 & .004 \\
\hline & & $1 \mathrm{~kg}$ & .000 & .000 \\
\hline \multirow[t]{3}{*}{3} & TAD - ATD & 500 & .000 & .000 \\
\hline & & 750 & .001 & .004 \\
\hline & & $1 \mathrm{~kg}$ & .000 & .000 \\
\hline
\end{tabular}

TAD (Tulang Ayam Dedak)

Tabel 5.

Hasil analisis perbandingan wadah dengan biomassa maggot Lokasi I dan II

\begin{tabular}{cccc}
\hline \hline \multirow{2}{*}{ No } & Media & \multicolumn{2}{c}{ Nilai Signifikansi } \\
\cline { 3 - 4 } & & Lokasi I & Lokasi II \\
\hline 1 & ATD & .780 & .662 \\
\hline 2 & AKD & .333 & .912 \\
\hline 3 & TAD & .651 & .681
\end{tabular}

Keterangan: ATD (Ampas Tahu Dedak), AKD (Ampas Kelapa Dedak), TAD (Tulang Ayam Dedak)

Biomassa maggot tertinggi dihasilkan melalui media campuran dedak dengan tulang ayam. Seperti yang telah diketahui, bahwa ayam mengandung protein, demikian juga tulangnya. Tingginya biomassa maggot dari hasil kultur media campuran dedak dengan tulang ayam dikarenakan oleh kandungan protein dalam tulang ayam. Secara metabolisme, maggot akan mengkonversi protein dan berbagai nutrien menjadi biomassa maggot. Gary (2009) bahwa maggot ini akan mereduksi nutrien yang terdapat di media sebesar 50-70\%.

Campuran dedak dengan ampas tahu menghasilkan biomassa maggot tertinggi kedua setelah media campuran dedak de-ngan tulang ayam. Hal ini menurut Silmina, dkk (2012) dapat terjadi karena komposisi ampas tahu yang merupakan media yang mengandung nutrisi (protein nabati) yang cukup. Namun tidak semua media perlakuan campuran dedak dengan ampas tahu menghasilkan maggot. Media ampas tahu yang digunakan untuk pertumbuhan maggot juga memiliki kadar air yang tinggi, hal itu tampak saat media ampas tahu yang digunakan masih basah.
Dan oleh karena kondisi air yang tinggi (basah) dapat menghambat pertumbuhan maggot (Anonim, 2010).

Media campuran dedak dengan ampas kelapa secara fisik dalam kondisi berminyak dan berjamur, karena hal itulah diduga lalat BSF tidak menetaskan telur dan larva (maggot). Tidak adanya maggot yang dihasilkan oleh karena media ampas kelapa yang digunakan masih mengandung air yang tinggi, dan hal ini menghambat perkembangbiakan maggot pada media tersebut.

\section{KESIMPULAN}

Berdasarkan hasil penelitian yang telah dilakukan dapat disimpulkan: 1) media campuran dedak dengan tulang ayam memiliki pengaruh yang signifikan terhadap biomassa maggot, dibandingkan dengan media campuran dedak dengan ampas tahu dan campuran dedak dengan ampas kelapa; 2) media campuran dedak dengan ampas kelapa tidak berpengaruh terhadap biomassa maggot; 3) penggunaan wadah yang berbeda tidak berpengaruh terhadap biomassa maggot; 4) kondisi media yang berminyak, dan terlalu basah (berair) tidak menghasilkan maggot.

Adapun saran yang dapat diberikan antara lain: 1) penempatan media kultur, sebaiknya memperhitungkan kondisi lingkungan, seperti kelembaban, dan ancaman dari hewan lain; 2) perlu adanya alat yang efisien dan efektif untuk memisahkan antara maggot BSF dengan larva lalat jenis lain; 3) perlu adanya penelitian lanjutan terkait efektivitas maggot dari media yang efektif sebagai pakan ternak.

\section{DAFTAR PUSTAKA}

Adrian, D. Desember 2015. Habitat Lalat Tentara dan Aplikasi sebagai Pakan. Diakses dari : http://lalattentara.blogspot.co. id/2015/12/habitat-lalat-tentara-danaplikasi.html (15 Juni 2016).

Anonim. September 2014. Kompos. Diakses dari: http://id.wikipedia.org/wiki/Kompos (10 Juni 2016).

Anonim. 2010. Dibiakkan Melalui Limbah Tahu. Artikel on-line (http://www.gizi.net) 
Balitbangtan (BB Veteriner). Maret 2016. Lalat Tentara Hitam Agen Biokonversi Sampah Organik Berprotein Tinggi. Diakses dari : http://www.litbang.pertanian.go.id/berita/on e/2557/ (10 Juni 2016)

Fahmi, M. R., Saurin H. dan Wayan S. 2007. Potensi Maggot Sebagai Salah Satu Sumber Protein Pakan Ikan. Loka Riset Budidaya Ikan Hias Air Tawar, Depok.

Gary. 2009. Black soldier fly larva. http://www. microponics.net (on-line). (9 Desember 2016)

Hartoyo dan Sukardi P. 2007. Alternatif Pakan Ternak Ikan. www.indopos.co.id (11 Juni 2016).

Katayane, Falicia A.; B. Bagau; F.R.Wolayan \& M.R.Imbar. Mei 2014. Produksi dan Kandungan Protein Maggot (Hermetia illucens) Dengan Menggunakan Media Tumbuh Berbeda. Jurnal zootek ("zootek journal") vol 34 (edisi khusus): 27 - 36 (Mei 2014) ISSN 0852-2626. Diakses dari: http://ejournal. unsrat.ac.id/index.php/zootek/article/viewFi le/4791/4314 (15 Juni 2016).

Murtidjo B. A. 2001. Pedoman Meramu Pakan Ikan. Yogyakarta. PT Kanisius

Newton L, Sheppard C, Watson DW, Burtle G, Dove R. 2005. Using the black soldier fly, Hermetia illucens, as a value-added tool for the management of swine manure. Report for The Animal and Poultry waste Management Center. North Carolina. North Carolina State University Raleigh.

Silmina, D., G. Edriani, \& M. Putri. 2012. Efektivitas Berbagai Media Budidaya Terhadap Pertumbuhan Maggot Hermetia illucens. (On line). Diakses dari: http://dosen. narotama.ac.id/wp-content/uploads/2012/03 /Efektifitas-Berbagai-Media-Budidaya-Terhadap-Pertumbuhan-Maggot-Hermetia-

illucens.pdf 